\title{
ASSESSMENT OF THE STATE OF HEALTH OF THE WOMEN WHO HAVE GIVEN BIRTH TO ALMOST HEALTHY NEWBORN CHILDREN Velikikh M.V. ${ }^{1}$, Kislyuk G.I. ${ }^{2}$ (Russian Federation) Email: Velikikh334@scientifictext.ru
}

\author{
${ }^{1}$ Velikih Maria Valeryevna - Student; \\ ${ }^{2}$ Kislyuk Galina Ivanovna - PhD in Medicine, Associate Professor, \\ DEPARTMENT OF PEDIATRICS, FACULTY OF POSTGRADUATE EDUCATION, \\ KURSK STATE MEDICAL UNIVERSITY, \\ KURSK
}

\begin{abstract}
: this article presents studies of the health indicators of mothers of 95 practically healthy children born in the regional perinatal center of Kursk in 2017. As follows from the results of the study, it is possible to draw conclusions about the low health indicators in the study group of women: an obstructed obstetric-gynecological anamnesis was found in $65.3 \%$, a high incidence - in $77.0 \%$, complicated during pregnancy and childbirth - in $98.9 \%$ of mothers, which made it possible to isolate these children in $2 A, 2 B$ health groups.

Keywords: pregnancy, childbirth, newborn children.

\section{ОЦЕНКА СОСТОЯНИЯ ЗДОРОВЬЯ ЖЕНЩИН, РОДИВШИХ ПРАКТИЧЕСКИ ЗДОРОВЫХ НОВОРОЖДЕННЫХ ДЕТЕЙ Великих М.В. ${ }^{1}$, Кислюк Г.И. ${ }^{2}$ (Российская Федерация)}

\author{
${ }^{1}$ Великих Мария Валерьевна - студент; \\ ${ }^{2}$ Кислюк Галина Ивановна - кандидат медииинских наук, доиент \\ кафедра педиатрии, факультет постдипломного образования, \\ Курский государственный медицинский университет, \\ 2. Курск
}

\begin{abstract}
Аннотация: в данной статье представлено исследование показателей здоровья матерей 95 практически здоровых детей, родившихся в областном перинатальном иентре г. Курска в 2017 году. Как следует из результатов проведенного исследования можно сделать выводы о низких показателях здоровья у исследованной группы женщин: отягощенный акушерско-гинекологический анамнез обнаружен у 65,3\%, высокая заболеваемость - у 77,0\%, осложненное течение беременности и родов - у 98,9\% матерей, что позволило выделить этих детей во $2 A, 2$ Б группы здоровья.
\end{abstract}

Ключевые слова: беременность, роды, новорожденные дети.

The state of health of mother and child is one of the key demographic indicators. Since the beginning of the 90th years in Russia along with low indicators of birth rate, the progressing increase in incidence of children (to 40-65\%), since the period of a neonatality [1, 2, 3]. Among chronic diseases at the pregnant woman, are registered more often: hypertension, pyelonephritis, obesity and so forth $[4,5,9]$. Presence of extragenitalny pathology at women of fertile age, brings to the pathological course of pregnancy and childbirth, the birth of children with high risk of realization of pathological states in the period of a neonatality $[6,7,8]$.

The purpose of this work: research of indicators of health, feature of a course of pregnancy and childbirth at mothers of clinically healthy newborn children.

Materials and methods: the analysis of 95 cards of pregnant women, stories of childbirth and stories of development of the healthy newborn children who were born in the regional perinatal center in Kursk in 2017 is carried out.

Results of a research: By us it is defined that 72,6\% of women in Kursk give birth at mature age, 25 years are more senior. Average age of mothers was 27,5 $\pm 5,3$ years, at the same time mothers are younger than 18 years were $4(4,2 \%)$, at the age of $18-24$ years $-22(23,2 \%)$, at the age of $25-28$ years $-40(42,1 \%)$ and 29 years are more senior - $29(30,5 \%) .34,7 \%$ of families have one child, 49,5\% - two children, 10,5\% - three and 5,3\% four and more children.

Attracts attention that there was a burdened obstetric and gynecologic anamnesis at $62(65,3 \%)$ mothers: abortions and miscarriage - on 13,6\%; the stood, extra-uterine pregnancy, the birth of extremely premature children - on $1,05 \%$, the death of the previous children of $-2,1 \%$. It is defined that chronic pathology of the sexual sphere takes place at $24(25,3 \%)$ mothers: erosion of a neck of the uterus $(15,8 \%)$, chronic adneksitis $(6,3 \%)$, the endometritis $(1,05 \%)$.

Specific weight of noninfectious gynecologic pathology among the examined women was 31,5\%: uterine myoma $(4,2 \%)$, infertility, cystic disease of ovaries - on $2,1 \%$, infantility $(1,05 \%)$; the uniformly narrowed pelvin $(11,6 \%)$, a scar on a uterus after the operational childbirth $(10,5 \%)$. It should be noted that the 
combination of 2 factors reflecting the burdened obstetric and gynecologic anamnesis is revealed at 27,4\% of women.

In the analysis of indicators of mothers's health it is revealed that only 22 women $(23,2 \%)$ consider themselves healthy from 95, various chronic diseases have been revealed at the others: $1 / 3$ of mothers have vegetovascular dystonia (on hypotonic type - at $32(33,6 \%)$, on hypertensive type - at 3(3,1\%); violation of fatty exchange - at $16 \%$, myopia - at 14,7\%, anemia - at 10,5\%, endocrine pathology - at 9,5\%, varicose vein disease - at $8,4 \%$, in isolated cases congenital anomalies of heart and kidneys, bronchial asthma and pollinosis are registered.Various infectious pathology is found in $65 \%$ of the examined women: gynecologic diseases - at 24 $(25,3 \%)$, chronic somatic diseases - at $47(49,5 \%)$, pyelonephritis, cystitis - at $24(25,3 \%)$, gastritis - at 8 $(8,4 \%)$, chronic the ENT SPECIALIST pathology - at 7 (7,5\%). And 4,5\% of mothers have two and more infectious and inflammatory diseases.

We have found the physiological course of pregnancy at $5(5,2 \%)$ mothers only, other $98,7 \%$ have various pathological states: infectious pathology $-61,0 \%$ of cases: ARVI $-14,7 \%$, pyelonephritis - 10,5\%, an infection of a genital tract (a colpitis $-26,3 \%$, platsentitis $-4,2 \%$, vaginitis $-2,1 \%$, syphilis $-3,15 \%$, carriage of the infection, transmitted sexually - 52,6\%; on the second place - anemia $(54,8 \%)$, on the third - a preeclampsia $(49,47 \%)$, threat of an abortion $(41,1 \%)$, chronic fetoplacental $(32,6 \%)$ and cervical $(8,5 \%)$ incompletence, gestational diabetes $(5,3 \%)$. The combination of infectious pathology and the states leading to development of FPI took place at $50,8 \%$ of mothers.

Screening on the infection, transmitted sexually was undergone $78(82 \%)$ pregnant women: negative results are received at $28(35,8 \%)$; immunoglobulins ( $\mathrm{IgG})$ to toxoplasma are found at $37(47,4 \%)$, to a rubella - at 8 $(10,2 \%)$, to a cytomegalovirus - at $7(7,7 \%)$, to a virus of simple herpes, a chlamydia and an ureaplasma - on $2,5 \%$ of women.

\section{Conclusion}

1. $72,6 \%$ of the examined women give birth at mature age, 25 years are more senior.

2. About $35 \%$ of families in Kursk have one child, $50 \%$ - two children, $15 \%$ - large families.

3. The burdened gynecologic anamnesis is found at $65,3 \%$ of mothers: abortions and miscarriage, the stood, extrauterine pregnancy $(29,4 \%)$, chronic inflammatory $(25,3 \%)$ and noninfectious $(31,5 \%)$ gynecologic diseases. The combination of 2 factors of the burdened gynecologic anamnesis is revealed at $1 / 3$ surveyed.

4. $77 \%$ of women have somatic diseases: vegetovascular dystonia $(36,8 \%)$, violation of fatty exchange $(16 \%)$, myopia $(14,7 \%)$, anemia $(10,5 \%)$, pathology of a thyroid gland and diabetes $(9,5 \%)$, varicose vein disease $(8,4 \%)$; chronic infectious and inflammatory $(65 \%)$. Two and more inflammatory diseases are revealed at $4,5 \%$ of women.

5. $98,7 \%$ of mothers had a complicated course of pregnancy: infectious pathology, anemia, preeclampsia, threat of an abortion and so forth.

6. $77,9 \%$ of mothers had a pathological course of childbirth: fast childbirth $-48,4 \%$, caesarean section $26,3 \%$, obstetric grants in labor $-3,2 \%$.

\section{References / Список литературы}

1. Abdurakhmanova D., Madaminova M. Feature of clinical symptomatology of a preeclampsia at the pregnant women living in the Priaralia region. // European Research, 2016. № 4. P. 163-165.

2. Gladkikh O., Yanchuk O., Kirilenko E., Kislyuk G. Features of the period of adatation at children with a delay of prenatal development // Collection of materials of «International congress on perinatal medicine». - 2011. - P. 71.

3. Dzhalilova G., Bakaeva J., Yusupova D. Health protection of women is a guara-tee of formation of healthy generation. // European Research,2016. № 4. P. 147-148.

4. Kislyuk G., Gladkikh O., Poshibaylova A., Shvechkova E. Features of postnatal development of children with a delay of prenatal growth and development. // Materials of the II international scientific and practical conference "Medicobiological aspects of multifactorial pathology", 2011. P. 159-161.

5. Kislyuk G., Velikikh M., Arkhipova A. Research of the perinatal anamnesis at almost healthy newborn children. // Materials of the international scientific and practical conference "Innovative science as basis of development of the modern state", 2017. P. 85-87.

6. Kovalyova N., Kislyuk G., Gladyshkina N. Some demographic indicators reflecting the state of health of mothers and newborn children in Kursk // Materials of the II international scientific and practical conference "Medicobiological aspects of multifactorial pathology", 2011. P. 197-198.

7. Snopkov V., Yakovlev A., Kislyuk G. The forecast of development of violations of the period of early neonatal adaptation at children from mothers with a tobacco addiction // Scientific sheets of the Belgorod state university, 2013. № 11. P. 195-198.

8. Pamfamirov Yu.K., Samoilenko A.V., Volokh A.A. Organ-preserving treatment of uterine myomas in patients of reproductive age. Bulletin of science and education, 2017. № 2 (26). Pp. 97-99. 
9. Shamkhalova I.A. Association of HLA-d genes in women with undeveloped pregnancy of the Azerbaijani population. Scientific research, 2017. № 3 (14). P. 42-45. 